\title{
Thermal Energy Optimization of Building Integrated Semi- Transparent Photovoltaic Thermal Systems
}

\author{
Ekoe A Akata Aloys Martial ${ }^{*}$, Donatien Njomo a and Basant Agrawal ${ }^{\mathrm{b}}$ \\ a Environmental Energy Technologies Laboratory (EETL), University of Yaoundé I, Cameroon \\ ${ }^{b}$ Centre for Energy Studies, Indian Institute of Technology Delhi, Hauz Khas, New Delhi 110 016, India
}

\begin{abstract}
Building integrated photovoltaic (BIPV) : The concept where the photovoltaic element assumes the function of power generation and the role of the covering component element has the potential to become one of the principal sources of renewable energy for domestic purpose. In this paper, a Building integrated semitransparent photovoltaic thermal system (BISPVT) system having fins at the back sheet of the photovoltaic module has been simulated. It has been observed that this system produces higher thermal and electrical efficiencies. The increase of wind velocity by fan system and heat exchange surface accelerates the convective heat transfer between the finned surface and the fluid flowing in the duct. The system area of $36.45 \mathrm{~m}^{2}$ is capable of annually producing an amount of thermal energy of $76.66 \mathrm{kWh}$ at an overall thermal efficiency of $56.07 \%$.
\end{abstract}

Keywords: Building Integrated Photovoltaic (BIPV), Solar Energy, Renewable Energy, Energy Conservation, Heat Transfer

Article History: Received February 16, 2015; Received in revised form May 17,2015; Accepted June 12,2015; Available online

How to Cite This Article: Ekoe, A.A.A., Njomo, D. and Agrawal, B. (2015) Thermal Energy Optimization of Building Integrated Semi-Transparent Photovoltaic Thermal Systems, 4(2), 113-123.

http://dx.doi.org/10.14710/ijred.4.2.113-123

\section{Introduction}

The LRE building at EPFL in LausanneSwitzerland, the NESTE Chemicals building in HelsinkiFinland, The Brundtland Centre atrium in ToftlundDenmark, etc. show that solar energy systems can play an important role in reducing building energy consumption (Hestnes 1999). Building integrated photovoltaic (BIPV) has significant influence on the heat transfer through the building envelope because of the change of the thermal resistance by adding or replacing building elements such as roof tiles, facade elements, and shading devices with photovoltaic modules that perform the same function but also provides electrical power. Ciampi et al. (2003) show that carefully designed ventilated facades, walls and roofs can considerably reduce the summer thermal loads.

The most rapidly expanding market in the development of building integrated photovoltaic thermal (BIPVT) systems is seen in the developing countries for onsite power generation and space heating (Tonui et al. 2008, Bazilian et al. 2002). The BIPVT is not widely use because its advantages compared to traditional PV modules and solar thermal collectors are unclear. Veronique et al. demonstrate that the BIPVT is more benefits than the simple integration (Véronique et al. 2014). Kimura (1994), Taleb et al. (2009), and Zhai et al. (2008) have illustrated various methods of installing PV modules into a building for a concept of green building. Fig.1 shows a brief classification of BIPVT systems.

Dapeng Li et al. (2015) investigates solar potential in urban residential buildings. They found that increasing building aspect ratio raise building solar potential. Infield et al. (2004) applied a steady state analysis model in a ventilated PV facade in order to evaluate an overall heat loss coefficient and thermal gain factor and suggested that the temperature of the PV module can be reduced by flowing air between the PV module and the double glass wall. Similar studies

*Corresponding Author: Ekoe A Akata; Tel: +237 76317345 / +237 96326443

Email: ekoealoys@yahoo.fr 
were carried out by Tripanagnostopoulos et al. (2002), Zondag et al. (2002), Prakash (1994) and Chow et al. (2003) by flowing air and water below the PV module to increase the electrical efficiency of the PV module. The design of the thermal collector is according to the fluids flowing in the duct (air or water) (Avezov 2011). Tiwari et al. (2006) have evaluated the performance of the photovoltaic (PV) module integrated with air duct for composite climate of India. Analytical expression for overall energy efficiency (electrical and thermal) has been derived. It is observed that there is a fair agreement between theoretical and experimental observations and concluded that an overall energy efficiency of photovoltaic thermal (PVT) system is significantly increased by utilization of thermal energy in PV module. Similar results were found by Khaled et al. (2013) and Parham et al. (2014). Maturi et al. (2015) applicated a heat sink on the PV module back side to improve its performance. They recommend that passive strategy could be considered an effective solution to reduce the module working temperature and consequently to slightly increase its energy performance

Four numerical models have been built for the simulation of the thermal yield of a combined PV thermal collector by Zondag et al. (2002). They found that for the calculation of the daily yield, the simple 1D steady state model performs almost as good as the much more time-consuming 3D dynamical model. Fung et al. (2008) presented a one-dimensional transient heat transfer model applicable to PV modules that have different orientations and inclinations, for evaluating the heat gain of semi-transparent photovoltaic modules for building integrated applications. Sarhaddi et al. (2011) developed a thermal and electrical model to calculate the solar cell temperature, back surface temperature, outlet air temperature, open-circuit voltage, short-circuit current, maximum power point voltage, maximum power point current, etc. of a typical photovoltaic thermal (PVT) air collector and found that the results of numerical simulation are in good agreement with the experimental measurements. A modified equation for the exergy efficiency of a PVT air collector is derived in terms of design and climatic parameters. João et al. (2014) compared the electric power generation of the photovoltaic panel with the solar radiation data. The photovoltaic system area of $16.5 \mathrm{~m}^{2}$ was installed on the campus of UNIVATES University Center. They found that the solar potential of $4.11 \mathrm{kWh} / \mathrm{m}^{2} /$ day is suitable for electricity generation from photovoltaic panels. Peyvand et al. (2014) Use a wind-driven roof top turbine ventilator equipped with a dynamo to cool down a photovoltaic (PV) cell. The experimental result of this combination show that is possible to reach an improvement of $46.54 \%$ in electricity production. Agrawal et al. (2010) optimized the opaque type BIPVT system for cold climatic conditions. The system fitted on the roof top of Srinagar over an effective area of $65 \mathrm{~m}^{2}$ produces annually the electrical and thermal exergy of $16209 \mathrm{kWh}$ and 1531 kWh. Agrawal et al. (2011) also evaluated a hybrid micro-channel photovoltaic thermal (MCPVT) module. Such system has increased the overall thermal and exergy gains by $70.62 \%$ and $60.19 \%$ respectively. Vats et al. (2012) evaluated a building integrated semitransparent photovoltaic thermal (BISPVT) system and found for an effective area of $5.44 \mathrm{~m}^{2}$ that the overall annual thermal energy gain is $2497 \mathrm{kWh}$ and electrical gain is $810 \mathrm{kWh}$. In this paper, analysis of the BISPVT is presented having fins at the back surface of PV modules.

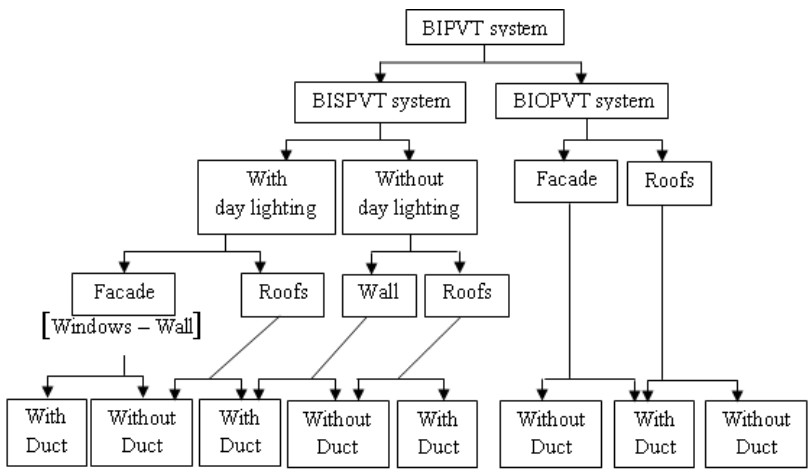

Fig. 1 Classification of BIPVT system

\section{Problem identification}

Building lighting represent more than $15 \%$ of energy consumption in residential building, 25 - $35 \%$ in office and commercial building in Cameroun. The electrical energy of BISPVT system of building under consideration is only used for the building light demand as $265 \mathrm{~W}$ for each apartment (20 apartments) and $100 \mathrm{~W}$ for corridor and outside light. The building under consideration is situated in Yaoundé at $3^{\circ} 52^{\prime} \mathrm{N}, 11^{\circ} 31^{\prime}$ E. The size of the building is $26.65 \mathrm{~m} \times 22.6 \mathrm{~m}$ with an average height of $15.3 \mathrm{~m}$. The roof is south oriented and inclined at $21^{\circ}$ to the horizontal. The building is insulated by a layer of sand and cement. Semitransparent photovoltaic thermal system is integrated as the roof top covering an effective area of $716.89 \mathrm{~m}^{2}$. Fig. 2 shows the pictorial view of the BISPVT system. The BISPVT system is made of multicrystalline PV modules having rectangular fins. The depth of the duct is $8.1 \mathrm{~m}$. The BISPVT system, area of $36.45 \mathrm{~m}^{2}$, and made up of $30 \mathrm{PV}$ modules and peak power of $5.4 \mathrm{~kW}$ is oriented in opposite direction with the wind to optimize the natural convection. The increases contact surface between the fluid flowing in the duct, by adding fins surfaces at the back sheet of PV module of BISPVT increase the heat exchange by convection, thereby decreasing the cells temperature while increasing the thermal energy extracted from the system. 


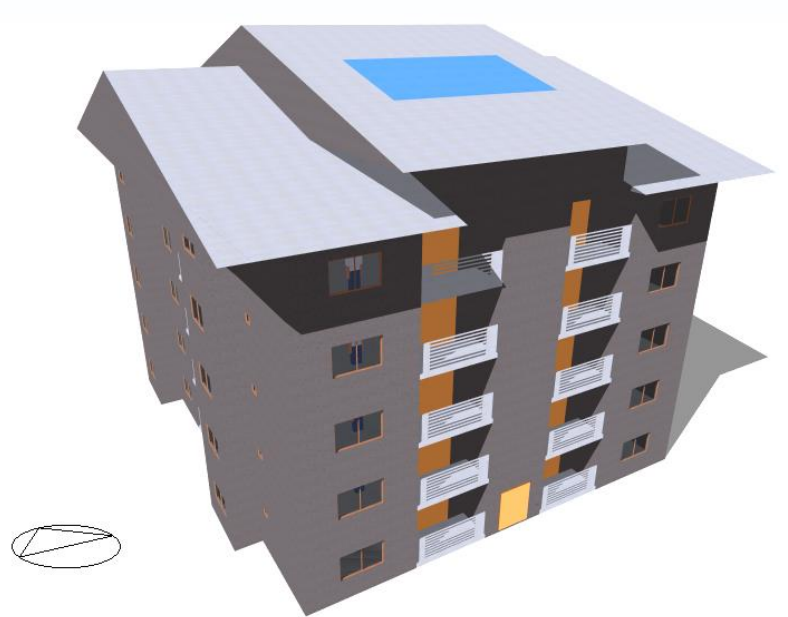

Fig. 2a Building model

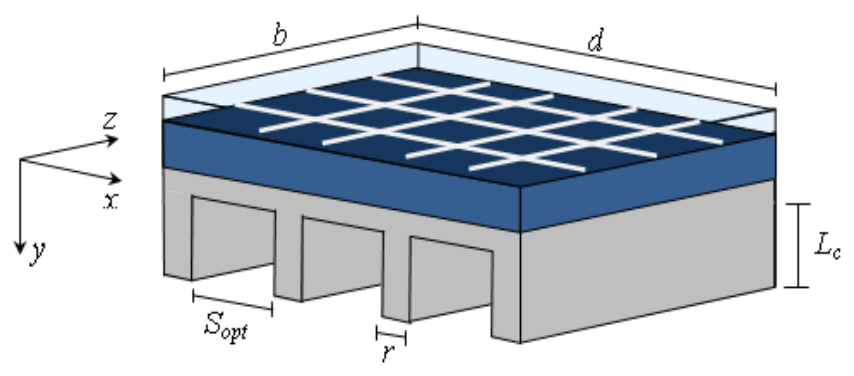

Fig. 2b PV module of BISPVT system

\section{Thermal modeling of BISPVT system}

The following assumptions have been made to write the energy balance equation of BISPVT system

- One dimensional heat conduction is considered for the present study

- The system is in quasi-steady state

- There is no temperature stratification in the air of a room and semitransparent photovoltaic module

- Glass cover and the photovoltaic module are at a uniform temperature

- Air properties are constant with time and temperature

The energy balance for the different components of the building integrated semitransparent photovoltaic thermal system is as follows:

\subsection{Glass cover of photovoltaic module}

We can start with the first law of thermodynamic as:

$U_{g}=Q_{g}+W_{g}$
$U_{g}=\rho_{g} V_{g} C_{g} \frac{d T_{g}}{d t}=0$ because of steady state system and $W_{g}=0$ for solid and

$$
\begin{aligned}
Q_{g}= & -\tau_{g} I(t)(b d x)+\alpha_{g} I(t)(b d x) \\
& +\frac{\lambda_{g}}{e_{g}}(b d x)\left(T_{c}-T_{g}\right)-h_{a}(b d x)\left(T_{g}-T_{a}\right)
\end{aligned}
$$

Eq. (1) can be rearranged as:

$$
-\tau_{g} I(t)+\alpha_{g} I(t)+\frac{\lambda_{g}}{e_{g}}\left(T_{c}-T_{g}\right)-h_{a}\left(T_{g}-T_{a}\right)=0
$$

\subsection{Solar cell of photovoltaic module.}

The energy balance equation of solar cell of photovoltaic module can also be started with the first law of thermodynamic as according to Fig. $2 \mathrm{~b}$ for an elemental area $b . d x$ :

$U_{c}=Q_{c}+W_{c}$

$U_{c}=\rho_{c} V_{c} C_{c} \frac{d T_{c}}{d t}=0$ (steady state system)

$W_{c}=0$ (for solid with no movement)

$$
\begin{aligned}
Q_{c}= & \left.\begin{array}{l}
{\left[\alpha_{c} \tau_{g} I(t)\right] \beta_{c}} \\
+\left[\alpha_{T} \tau_{g} I(t)\right]\left(1-\beta_{c}\right)
\end{array}\right)(b d x) \\
& -\eta_{c}\left[\alpha_{c} \tau_{g} I(t)\right] \beta_{c}(b d x) \\
& -\left(\frac{e_{g}}{\lambda_{g}}+\frac{1}{h_{a}}\right)^{-1}(b d x)\left(T_{c}-T_{a}\right) \\
& -\frac{\lambda_{b s}}{e_{b s}}(b d x)\left(T_{c}-T_{b s}\right)
\end{aligned}
$$

By substituting $U_{c}, W_{c}$ and $Q_{c}$ in Eq. (3), we obtained:

$$
\begin{aligned}
& \tau_{g} \alpha_{c} \beta_{c} I(t)+\tau_{g} \alpha_{T}\left(1-\beta_{c}\right) I(t)-\tau_{g} \alpha_{c} \beta_{c} \eta_{c} I(t) \\
& -\left(\frac{e_{g}}{\lambda_{g}}+\frac{1}{h_{a}}\right)^{-1}\left(T_{c}-T_{a}\right)-\frac{\lambda_{b s}}{e_{b s}}\left(T_{c}-T_{b s}\right)=0
\end{aligned}
$$

The solar cell temperature can be obtained with Eq. (4) as (Vats et al. 2012, Dubey et al. 2009):

$$
T_{c}=\frac{\left(\frac{e_{v}}{\lambda_{v}}+\frac{1}{h_{a}}\right)^{-1} T_{a}+\left(\frac{e_{b s}}{\lambda_{b s}}\right)^{-1} T_{b s}+\tau_{v}\left[\alpha_{c} \beta_{c}+\alpha_{T}\left(1-\beta_{c}\right)-\alpha_{c} \beta_{c} \eta_{c}\right] I(t)}{\left(\frac{e_{v}}{\lambda_{v}}+\frac{1}{h_{a}}\right)^{-1}+\left(\frac{e_{b s}}{\lambda_{b s}}\right)^{-1}}
$$




\subsection{Back sheet of PV module}

\section{Heat}

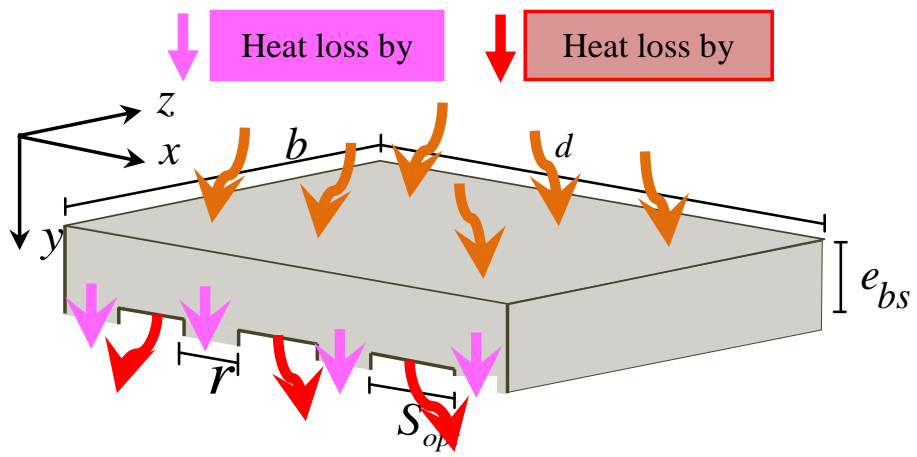

Fig. 3 Thermal energy at the back sheet of PV module

Following Fig. 3, energy balance for back surface of PV module is:

$$
\begin{aligned}
h_{b s} b d\left(T_{c}-T_{b s}\right)= & h_{f} b\left(d-n_{f i n} r\right)\left(T_{b s}-T_{f}\right) \\
& -\left.\lambda_{b s} b r n_{f i n} \frac{\partial T}{\partial y}\right|_{y=e_{b s}}
\end{aligned}
$$

and

$$
\begin{array}{ll}
\frac{\partial^{2} T}{\partial y^{2}}=0 & 0 \leq y \leq e_{b s} \\
T=T_{c} & y=0 \\
T=T_{b s} & y=e_{b s}
\end{array}
$$

After resolving Eq. (7), we obtained

$$
\left.\frac{\partial T}{\partial y}\right|_{y=e_{b s}}=\frac{T_{b s}-T_{c}}{e_{b s}}
$$

Substituting Eq. (8) in Eq. (6), the back surface temperature is

$$
T_{b s}=\frac{\left(\frac{e_{b s}}{\lambda_{b s}}\right)^{-1}\left(d-n_{f i n} r\right) T_{c}+h_{f}\left(d-n_{f i n} r\right) T_{f}}{\left(d-n_{f i n} r\right)\left(\left(\frac{e_{b s}}{\lambda_{b s}}\right)^{-1}+h_{f}\right)}
$$

The convective coefficient between the back sheet of PV module and the air in the gap can be obtained as:

$$
h_{f}=\frac{N u \lambda_{b s}}{D_{d u}}
$$

$$
D_{d u}=\frac{4 A_{d u}}{P_{d u}}
$$

$\mathrm{Nu}$ is the average Nusselt number for the thermal entrance region of flows between isothermal parallel plate of length $L_{c}$ expressed as (Özışık , 1985)

$$
N u=7,54+\frac{0,03\left(D_{d u} / L_{c}\right) \operatorname{Re} \operatorname{Pr}}{1+0,016\left[\left(D_{d u} / L_{c}\right) \operatorname{RePr}\right]^{2 / 3}}
$$

For forced convection and

$N u=\frac{h_{f} S}{\lambda_{b s}}=\left[\frac{576}{\left(R a_{S} S / L_{c}\right)^{2}}+\frac{2,873}{\left(R a_{S} S / L_{c}\right)^{0,5}}\right]^{-0,5}$

For natural convection and the Rayleigh number $R a_{S}$ is expressed as:

$R a_{S}=\frac{g \beta\left(\overline{T_{b}}-T_{f}\right) S^{3}}{v^{2}} \operatorname{Pr}$

\subsection{Fin surface of Back sheet of PV module}

Following Fig. 4, the energy balance equation of the fin is :

$\phi_{\text {in }}+\phi_{\text {generated }}=\phi_{\text {out }}+\phi_{\text {stay in }}$

Eq. (15) gives

$A_{b s} \lambda_{b s} \frac{d^{2} T_{b}}{d y^{2}} . \Delta y+h_{f}\left(T_{f}-T_{b}\right) P . \Delta y=0$

$\Delta y$ is canceled and the result is rearranged to

$$
\begin{array}{lc}
m^{2}=\frac{h_{f} P}{A_{b s} \lambda_{b s}} ; & \theta_{b}=T_{b}-T_{f} \\
\frac{d^{2} \theta_{b}}{d y^{2}}-m^{2} \theta_{b}=0 & 0 \leq y \leq L \\
\theta_{b}=T_{b s}-T_{f} & y=0 \\
\lambda_{b s} \frac{d \theta_{b}}{d y}+h_{f} \theta_{b}=0 & y=L
\end{array}
$$

Then, expression of fin surface temperature is obtained as: 
$\frac{T_{b}-T_{f}}{T_{b s}-T_{f}}=\frac{\cosh [m(L-y)]+\frac{h_{f}}{m \lambda_{b s}} \sinh [m(L-y)]}{\cosh (m L)+\frac{h_{f}}{m \lambda_{b s}} \sinh (m L)}$

(18)

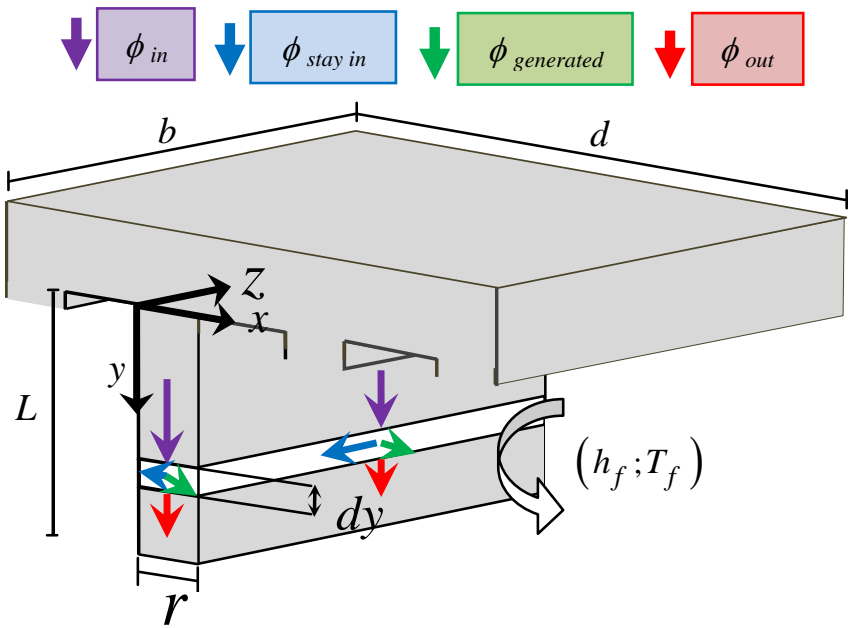

Fig. 4 Thermal energy of fin

The accurate boundary condition for the fin tip is to take account of heat conduction and radiation. Generally, the fin tip area is very small in comparison with his total surface so that, the effect of radiation can be negligible. A practical way of accounting for the heat loss from the fin tip is to replace the fin length $L$ in the relation for the insulated tip case by a corrected length defined as:

$L_{c}=L+\frac{A_{c}}{P}=L+\frac{r}{2}$

Finally, the temperature expression of fin is given as

$T_{b}(y)=\frac{\cosh \left[m\left(L_{c}-y\right)\right]}{\cosh \left(m L_{c}\right)}\left(T_{b s}-T_{f}\right)+T_{f}$

The optimum space $S_{\text {opt }}$ between two fin surface that maximizes convection heat transfer for a given base area b.d, can be obtained as (Cengel , 2003):

$S_{o p t}=2,714\left(\frac{S^{3} d}{R a_{S}}\right)^{0,25}=2,714 \frac{d}{R a_{d}{ }^{0,25}}$

Where the Rayleigh number is expressed as :

$R a_{d}=\frac{g \cos \theta\left(\overline{T_{b}}-T_{f}\right) \beta d^{3}}{v^{2}} \operatorname{Pr}$

The mean fin temperature $\overline{T_{b}}$ is given by :
$\overline{T_{b}}=\frac{1}{L_{c}} \int_{0}^{L_{c}} T_{b}(y) d y=T_{f}+\frac{T_{b s}-T_{f}}{m L_{c}} \frac{\sinh \left(m L_{c}\right)}{\cosh \left(m L_{c}\right)}$

and the number of fin is :

$n_{\text {fin }}=\frac{d}{S_{\text {opt }}+r}$

\subsection{Air flowing in a duct}

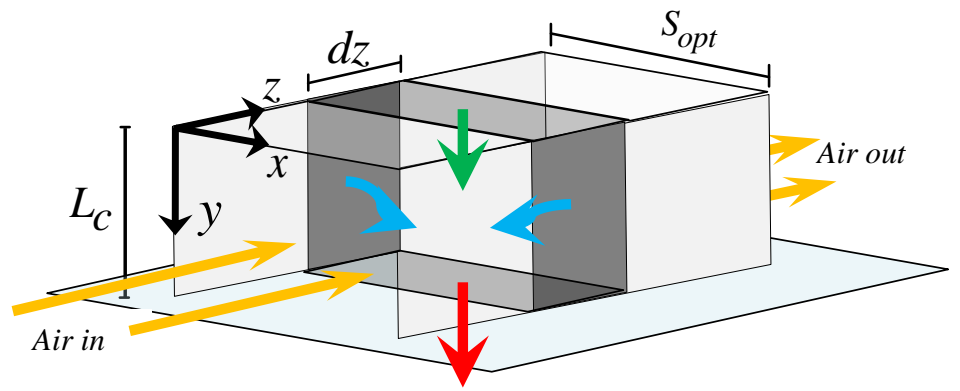

Fig. 5 Air flowing in the duct

Following Fig.5 for each duct, energy balance for air flowing in the duct of the BISPVT system is given as:

$$
\begin{aligned}
& h_{f}\left(T_{b s}-T_{f}\right) S_{o p t} d z+2 h_{f}\left(\overline{T_{b}}-T_{f}\right) L_{c} d z= \\
& \dot{m}_{f} c_{f} \frac{d T_{f}}{d z} d z+U_{\text {ins }}\left(T_{f}-T_{r}\right) S_{o p t} d z
\end{aligned}
$$

On integrating Eq. (25) with boundary condition $T_{f}(z=0)=T_{\text {air,in }}$ and $T_{f}(z=b)=T_{\text {air, out }}$ the flowing air temperature of BISPVT system for each duct of back sheet of PV module is given by

$$
T_{f}(z)=\left(T_{a i r, i n}-\frac{F_{f}}{G_{f}}\right) \exp \left(-G_{f} z\right)+\frac{F_{f}}{G_{f}}
$$

Where

$$
\begin{gathered}
G_{f}=\frac{1}{\dot{m}_{f} c_{f}}\left[\begin{array}{l}
\left(h_{f} S_{o p t}+\frac{2 h_{f}}{m} \frac{\sinh \left(m l_{c}\right)}{\cosh \left(m l_{c}\right)}\right)\left(1-\frac{h_{f}\left(U_{T}+h_{b s}\right)}{\left(h_{b s}+h_{f}\right)\left(U_{T}+h_{b s}\right)-h_{b s}^{2}}\right) \\
+U_{\text {ins }} S_{\text {opt }}
\end{array}\right] \\
F_{f}=\frac{U_{\text {ins }} S_{\text {opt }}}{\dot{m}_{f} c_{f}} T_{r}+\frac{1}{\dot{m}_{f} c_{f}}\left[\begin{array}{l}
h_{f} S_{o p t}+ \\
\frac{2 h_{f}}{m} \frac{\sinh \left(m l_{c}\right)}{\cosh \left(m l_{c}\right)}
\end{array}\right] \frac{h_{b s}\left[U_{T} T_{a}+I(t) \cdot(\tau \alpha)_{e f f}\right]}{\left(h_{b s}+h_{f}\right)\left(U_{T}+h_{b s}\right)-h_{b s}{ }^{2}}
\end{gathered}
$$

and the average air temperature of the air flowing in each duct of back sheet of PV module is given by 


$$
\begin{aligned}
\overline{T_{f}} & =\frac{1}{b} \int_{0}^{b} T_{f}(z) d z \\
& =\frac{F_{f}}{G_{f}}+\frac{1}{G_{f} b}\left(T_{a i r, i n}-\frac{F_{f}}{G_{f}}\right)\left[1-\exp \left(-G_{f} b\right)\right]
\end{aligned}
$$

The rate of useful thermal energy obtained for $n_{P V}$ module of BISPVT system is given by

$$
\dot{Q}_{\text {useful,heat }}=n_{P V}\left[n_{d u} \dot{m}_{f} c_{f}\left(T_{\text {air }, \text { out }}-T_{r}\right)\right]
$$

when air flowing in ducts is used to warm the ambient air inside the building or given as :

$\dot{Q}_{\text {useful }, \text { cool }}=-n_{P V}\left[n_{d u} \dot{m}_{f} c_{f}\left(T_{\text {air }, \text { out }}-T_{\text {air }, \text { cool }}\right)\right]$

when air flowing in ducts is to be used in a cooling system.

The outlet air temperature of the flowing air in each duct of the BISPVT system is

$T_{\text {air }, \text { out }}=\left(T_{\text {air }, \text { in }}-\frac{F_{f}}{G_{f}}\right) \exp \left(-G_{f} b\right)+\frac{F_{f}}{G_{f}}$

\subsection{Building air temperature}

The energy balance equation for the air in the building is given by

$$
\phi_{r, \text { in }}+\phi_{r, \text { generated }}=\phi_{r, \text { out }}+\phi_{r, \text { stay in }}
$$

Considering the Eq. (30) only for heat transfer through the building envelope, we obtained:

$$
\begin{aligned}
\dot{m}_{r} c_{\text {air }} \frac{d T_{r}}{d t}= & \dot{Q}_{\text {useful, heat /cool }}+(U A)_{t}\left(T_{a}-T_{r}\right) \\
& +U_{\text {ins }} A_{\text {BISPVT }}\left(\overline{T_{f}}-T_{r}\right) \\
& -0,33 N_{o} V\left(T_{a}-T_{r}\right)
\end{aligned}
$$

On solving Eq. (31) and applying the initial condition $T_{r}(t=0)=T_{r i}$, the building air temperature is obtained as

$$
T_{r}=\left(T_{r i}-\frac{F_{r}}{G_{r}}\right) \exp \left(-G_{r} t\right)+\frac{F_{r}}{G_{r}}
$$

Where

$$
G_{r}=\frac{1}{m_{r} c_{\text {air }}}\left[\begin{array}{l}
n_{p v} n_{d u} \dot{m}_{f} c_{f}\left(1-\frac{U_{i n s} S_{o p t}}{G_{f} \dot{m}_{f} c_{f}}\left(1-e^{-G_{f} b}\right)\right) \\
+(U A)_{t}-0.33 N_{0} V \\
+U_{\text {ins }} A_{\text {bispvt }}\left(1-\frac{U_{\text {ins }} S_{o p t}}{G_{f} \dot{m}_{f} c_{f}}\left(1-\frac{1-e^{-G_{f} b}}{G_{f} b}\right)\right)
\end{array}\right]
$$

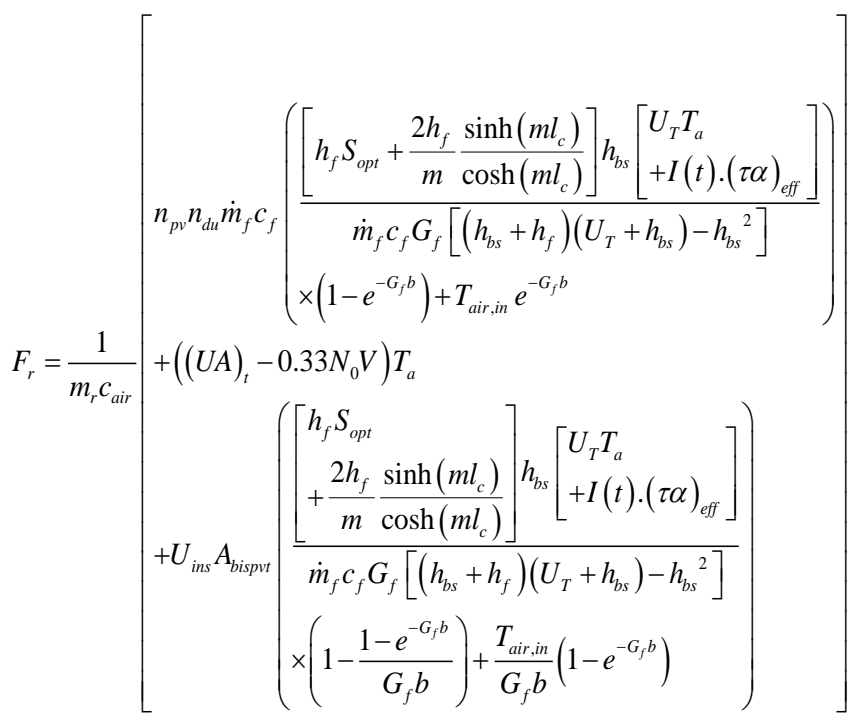

\subsection{Electrical energy, thermal energy and exergy of BISPVT system}

\subsubsection{Electrical energy of BISPVT system}

According to vats (Vats et al. 2012), the hourly electrical efficiency of the PV module is given by

$$
\begin{aligned}
& \eta_{P V, \text { hourly }}=\eta_{\text {ref }, P V}\left[1-\beta_{r e f, P V}\left(T_{c, \text { hourly }}-25\right)\right] \\
& \eta_{T H, \text { hourly }}=\frac{\frac{\eta_{P V, \text { hourly }} I(t) n_{P V} A_{\text {bispvt }}}{C_{f}}+Q_{u s e f u l, \text { hourly }}}{I(t) n_{P V} A_{\text {bispvt }}}
\end{aligned}
$$

Where $\eta_{\text {ref }, P V}$ and $\beta_{\text {ref ,PV }}$ are module efficiency and temperature coefficient for different PV materials. The electrical power is

$$
\eta_{T H, \text { hourly }}=\frac{\frac{\eta_{P V, \text { hourly }} I(t) n_{P V} A_{\text {bispvt }}}{C_{f}}+Q_{\text {useful }, \text { hourly }}}{I(t) n_{P V} A_{b i s p v t}}
$$




$$
\begin{aligned}
& E_{\text {el,hourly }}=\eta_{P V, \text { hourly }} A_{\text {BISPVT }} I(t)_{h o u r l y} \\
& E_{e l, \text { daily }}=\sum_{i=1}^{N_{1}} E_{e l, \text { hourly }, i} \\
& E_{e l, \text { monthly }}=n_{o} E_{e l, \text { daily }} \\
& E_{\text {el,annual }}=\sum_{j=1}^{12} E_{\text {el,monthly }, j}
\end{aligned}
$$

where $N_{1}$ and $n_{o}$ are the number of sunshine hours per day and the number of clear days in a month

\subsubsection{Thermal energy of BISPVT system}

The thermal energy is calculated as:

$$
\begin{aligned}
& Q_{\text {th }, \text { daily }}=\sum_{i=1}^{N_{1}} Q_{\text {useful }, \text { hourly }, i} \\
& Q_{\text {th, monthly }}=\sum_{j=1}^{n_{o}} Q_{\text {th }, \text { daily }, j} \\
& Q_{\text {th, annual }}=\sum_{k=1}^{12} Q_{\text {th }, \text { monthly }, k}
\end{aligned}
$$

\section{Methodologies}

In order to obtain the dynamic behavior of the system, as well as estimating the outlet air temperature from the duct of PV module for different season of the year, we used hourly global and diffuse solar radiation data of a representative day of each month (Klein day) over Yaoundé region for the 2011 year obtained from the Energy and Environmental Technologies Laboratory of the Department of Physics at the University of Yaoundé I; we also used climatic data issued by the Atmospheric Physics Laboratory.

- The total solar radiation over inclined roof $\left(21^{\circ}\right)$ is obtained as (Duffie 2013)

$$
\begin{aligned}
I(t)= & {\left[I_{g}(t)-I_{d}(t)\right] R_{b}+\frac{1}{2}(1+\cos \theta) I_{d}(t) } \\
& +\frac{1}{2}(1-\cos \theta) \rho_{a l b} I_{g}(t)
\end{aligned}
$$

- The expression of cell temperature from Eq. (5) is introduced in Eq. (9) to have expression of back sheet of PV temperature as a function of fluid temperature.

- $\quad$ The difference $\bar{T}_{b}-T_{f}$ is derived from Eq. (23)
These expressions are introduced in Eq. (25) and integrated to have the air flow temperature expression (Eq. (27)) and Eq. (28) are used to solve Eq. (31)).

- The hourly thermal energy is obtained with the help of Eq. (28).

- The hourly thermal energy from fin to air flowing in the duct is obtained with the help of Eq. (37)

$$
Q_{\text {fin-air }}=n_{\text {fins }}\left(2 L_{c} b\right) h_{f}\left(T_{b}-T_{f}\right)
$$

- The overall electrical and thermal efficiency are calculated by using Eq. (33).

- Design specification and operating parameters of the building are presented in tables 1 . These have been used as input parameters for energy analysis.

Table 1.

Design parameters of a building and semitransparent PV module

\begin{tabular}{ll}
\hline Parameters & Values \\
\hline $\mathrm{b}$ & $8.1 \mathrm{~m}$ \\
$\mathrm{~d}$ & $4.5 \mathrm{~m}$ \\
PV roof area & $36,45 \mathrm{~m}^{2}$ \\
Roof inclination & $21^{\circ}$ \\
Volume of building & $7152 \mathrm{~m}^{3}$ \\
$\mathrm{C}_{\mathrm{f}}$ & 0.38 \\
Cair & $1005 \mathrm{~J} \mathrm{~kg}^{-1} \mathrm{~K}^{-1}$ \\
$\alpha_{C}$ & 0.9 \\
$\alpha_{T}$ & 0.5 \\
$\beta_{C}$ & 0.83 \\
$\tau_{g}$ & 0.9 \\
$\eta_{C}$ & 0.12
\end{tabular}

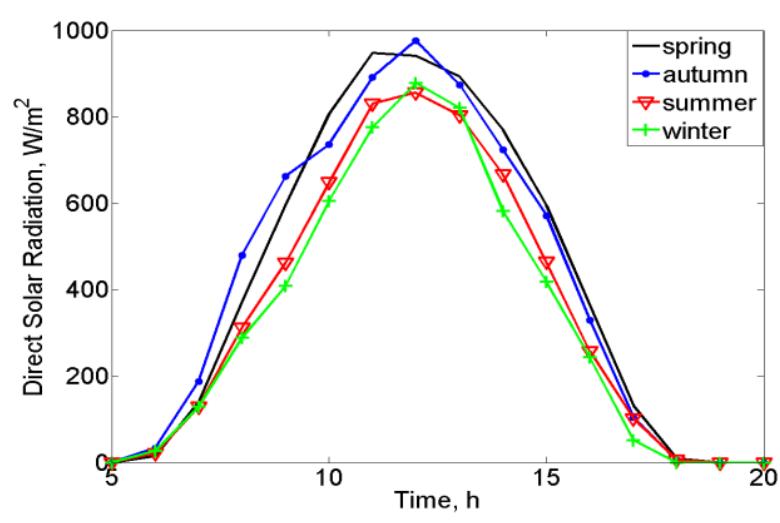

Fig. 6 Total solar radiation over inclined surface 


\section{Results and Discussions}

The variations of total solar intensity in Yaoundé for the four seasons of the year 2011 obtained from the Environmental Energy Technologies Laboratory (EETL) at the University of Yaoundé I are shown in Fig. 6. The values of various design parameters of the building and the semitransparent PV modules are given in Table.1. The hourly variation of cell temperature, outlet air temperature, fin temperature and room air temperature are shown in Fig. 7. From these figures, it is observed that the maximum temperature is $59.32{ }^{\circ} \mathrm{C}$ for cell temperature, $40.53^{\circ} \mathrm{C}$ for fins surface obtained at $12: 00$ a.m. for the autumn season. Many studies cited above demonstrate that cell temperature can be up above to this value when heat is not and rapidly extracted at the back sheet of PV module. The outlet air temperature varies from $24{ }^{\circ} \mathrm{C}$ to $37.69{ }^{\circ} \mathrm{C}$ and the room air temperature varies from $23.41{ }^{\circ} \mathrm{C}$ to $35.81{ }^{\circ} \mathrm{C}$. Peak values temperatures are also observed at 12:00 a.m. We can note that the heat absorbed by the air flowing in the duct at the back sheet of PV module increase the air temperature to $10{ }^{\circ} \mathrm{C}$ at 12:00 a.m. This heat absorbed depends on the physical and thermal properties of the duct, the fluid flowing, the movement and the velocity of the fluid in the duct. These results were obtained by considering the building as one piece without internal heat source. In addition, the heat transfer model for the indoor air temperature of the building is simplistic. The heat loss due to ventilation (mechanical or natural) of the building is not sufficiently taken into account in the model.

The hourly thermal energy is shown in Fig. 8. and Fig. 9 shows the hourly electrical and thermal efficiency of the BISPVT system. From, the above figures, it is observed that an increase in cell temperature decreases the cell efficiency. So it is necessary to have a way to decrease cell temperature for BISPVT electrical efficiency optimization.

The hourly variation of heat received from fins surfaces to air flowing in the duct is shown in Fig. 10. From the figure, it is observed that the maximum value of heat is $25.485 \mathrm{Wh}$. In a year, heat extracted by air from fin surface is $55.4 \mathrm{kWh}$. This heat can be optimized when the duct is well designed. A heat sink with closely packed fins will have greater surface area for heat transfer but a smaller heat transfer coefficient. A heat sink with widely spaced fins, on the other hand, will have a higher heat transfer coefficient but a smaller surface area. The optimum spacing that maximizes convection heat transfer optimizes the heat transfer between the finned surface and the fluid flowing in the duct.

Fig. 11 shows the variation of the maximum value of cell temperature and electrical efficiency with the convection coefficient of fluid flowing in the duct for 12.00 a.m. It is observed that the maximum value of cell temperature decreased from $62.68{ }^{\circ} \mathrm{C}$ to $53.75{ }^{\circ} \mathrm{C}$ corresponding to an increase of the electrical efficiency of $0.75 \%$ for a constant wind velocity of $0.9 \mathrm{~m} \mathrm{~s}^{-1}$.

The variation of cell temperature and electrical efficiency with wind velocity of air flowing in the duct is shown in Fig. 12. It is observed that an increase of the wind velocity by a fan system from $0.1 \mathrm{~ms}^{-1}$ to $5 \mathrm{~ms}^{-1}$ decreases cell temperature from $66.92{ }^{\circ} \mathrm{C}$ to $43.3{ }^{\circ} \mathrm{C}$ corresponding to an increase of the electrical efficiency of $1.54 \%$ at a constant convection coefficient of fluid flowing in the duct of $5 \mathrm{~W} / \mathrm{m}^{2} \mathrm{~K}$.

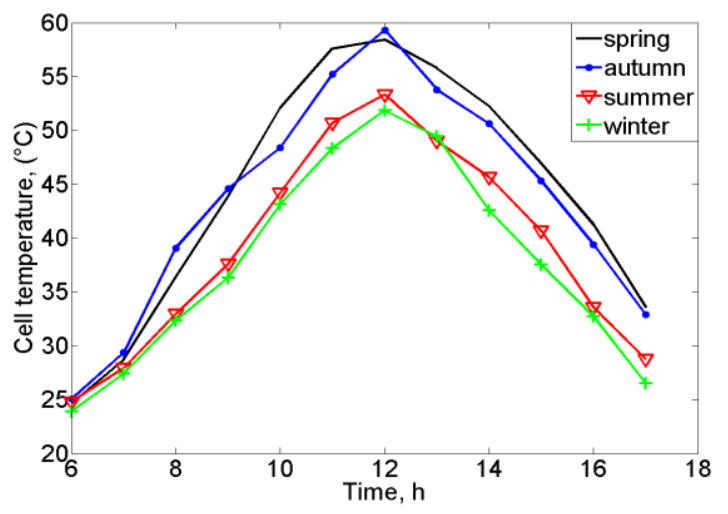

Fig. 7a Cell temperature

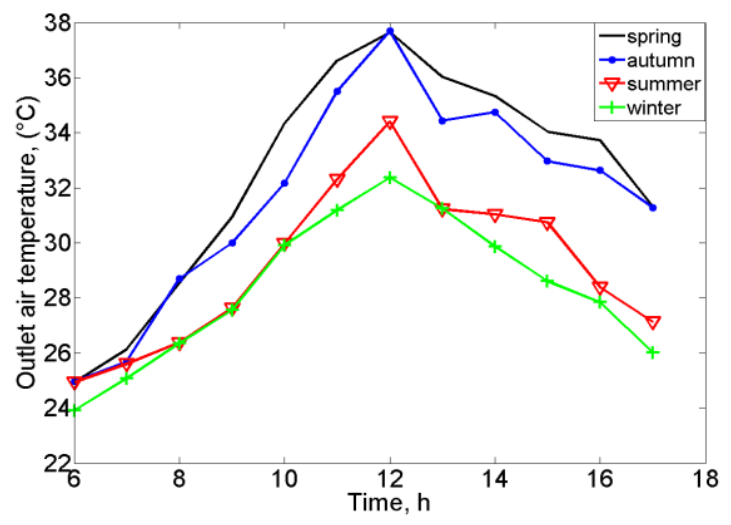

Fig. 7b Outlet air temperature

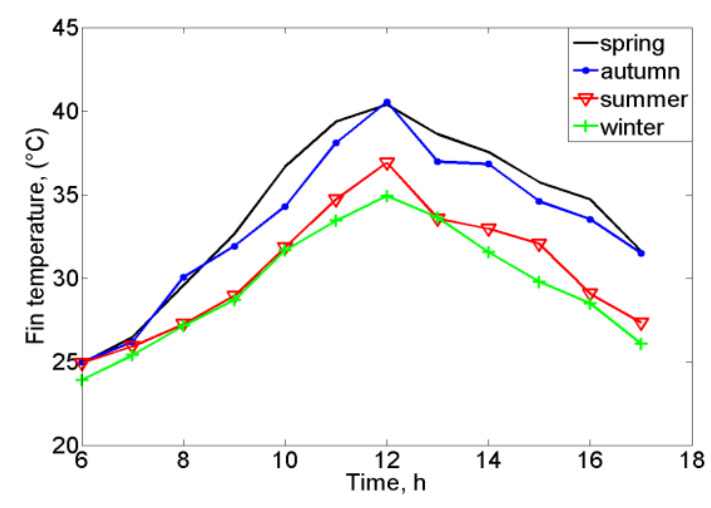

Fig. 7c Fin temperature 


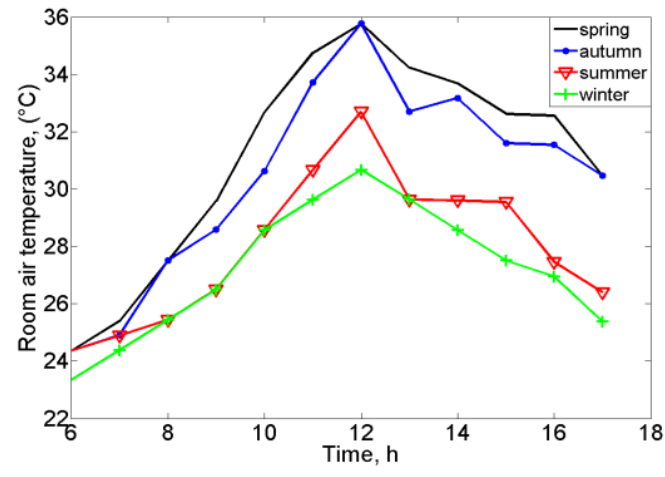

Fig. 7d Room air temperature

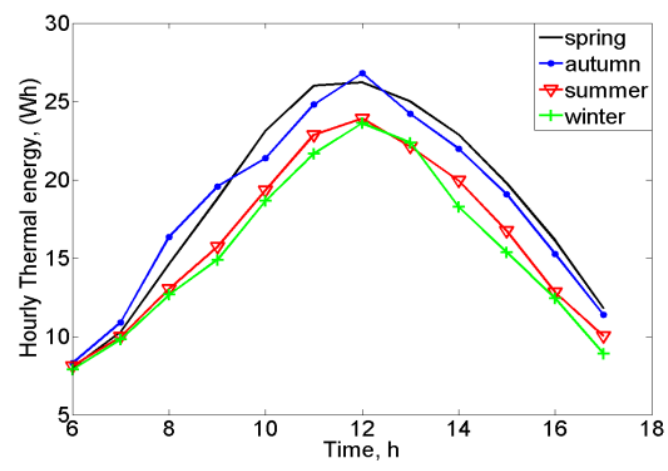

Fig. 8 Hourly thermal energy

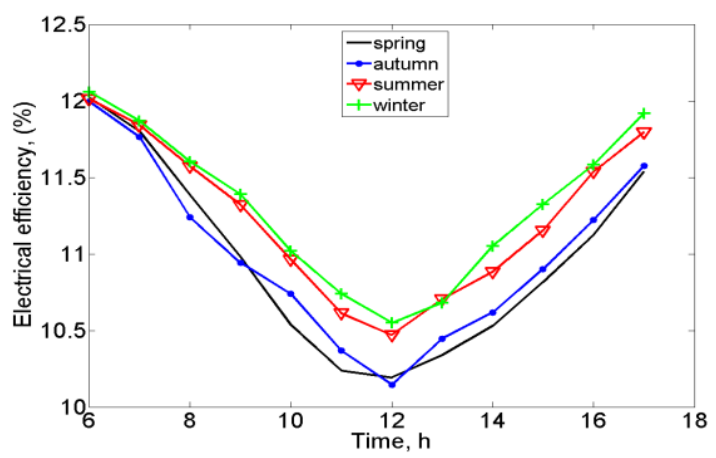

Fig. 9a Hourly Electrical efficiency

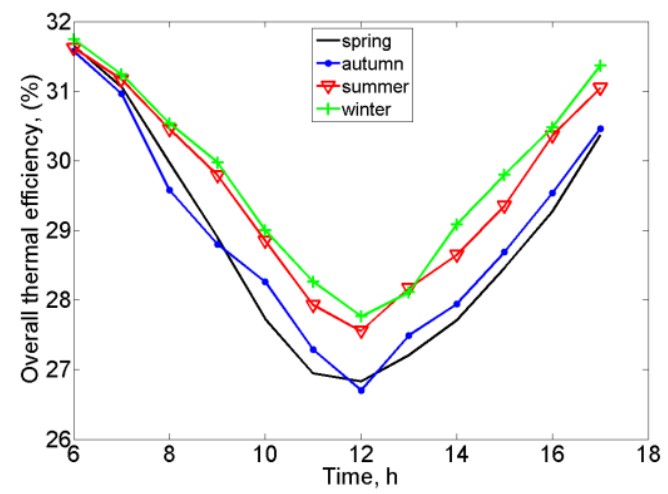

Fig. 9b Hourly Thermal efficiency

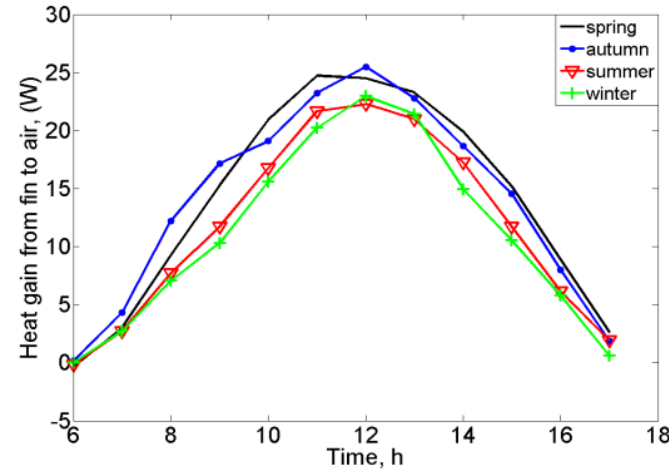

Fig. 10 Heat received from fin to air flowing
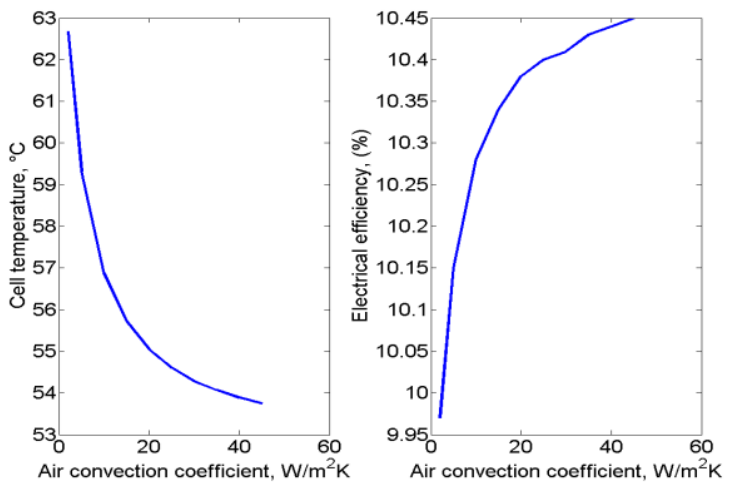

Fig. 11 Cell temperature and electrical efficiency with air convection coefficient
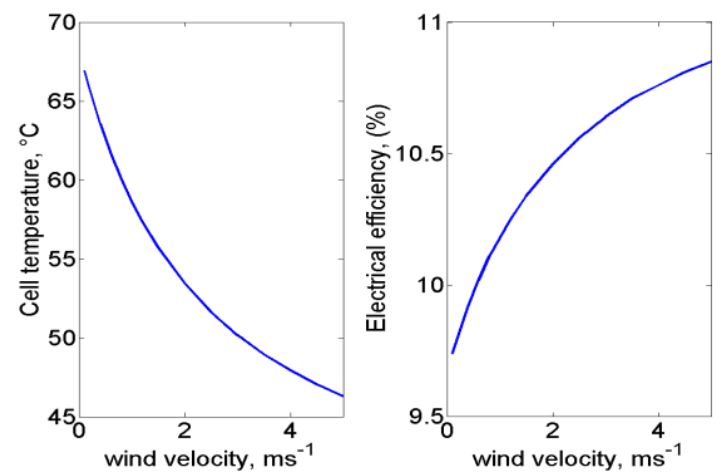

Fig. 12 Cell temperature and electrical efficiency with wind velocity

\section{Conclusion}

The thermal analysis of a building integrated semitransparent photovoltaic system with fins at the back surface of the PV module to increase the thermal energy of fluid flowing in the duct has been studied. It has been observed that:

- the decrease of cell temperature increases the electrical efficiency of PV module

- The maximum value of heat received from fins surfaces to air flowing in the duct is $25.485 \mathrm{Wh}$ and heat extracted by air from the fin surface in a year is $55.4 \mathrm{kWh} /$ year. 
- an increase in the flow velocity of air flowing in the duct of BISPVT system from 0.1 to $5 \mathrm{~ms}^{-1}$ by a fan system can decreases the cell temperature from $66.92{ }^{\circ} \mathrm{C}$ to $43.3^{\circ} \mathrm{C}$ corresponding to an increase of the electrical efficiency of $1.54 \%$

The BISPVT system studied produces a maximum annual thermal energy of $76.66 \mathrm{kWh}$ with an overall thermal efficiency of $56.07 \%$.

\section{Appendix A}

$$
\begin{aligned}
& (\tau \alpha)_{e f f}=\tau_{g}\left[\alpha_{c} \beta_{c}+\alpha_{T}\left(1-\beta_{c}\right)-\alpha_{c} \beta_{c} \eta_{c}\right] \\
& U_{T}=\left(\frac{e_{g}}{k_{g}}+\frac{1}{h_{0}}\right)^{-1} \\
& U_{\text {ins }}=\left(\frac{e_{A l}}{k_{A l}}+\frac{1}{h_{0}}+\frac{e_{c p l}}{k_{c p l}}\right)^{-1} \\
& h_{0}=5.7+3.8 v \\
& h_{b s}=\left(\frac{e_{b s}}{k_{b s}}\right)^{-1}
\end{aligned}
$$

\section{Nomenclature}

A $\quad$ area $\left(\mathrm{m}^{2}\right)$

$b \quad$ height of the BISPVT system (m)

c specific heat $(\mathrm{J} / \mathrm{kg} \mathrm{K})$

$d \quad$ width of the BISPVT system (m)

$d x \quad$ elemental length (m)

dy elemental length (m)

$d z \quad$ elemental length (m)

$d t \quad$ elemental time (s)

D hydraulic diameter (m)

$e \quad$ thickness (m)

$g$ thermal gain factor

$h$

$k$

$L$

$L c$

$\dot{m}$

$n$

$\mathrm{Nu}$

$\mathrm{Pr}$

\begin{tabular}{|c|c|}
\hline$I(t)$ & Incident solar radiation $\left(\mathrm{W} / \mathrm{m}^{2}\right)$ \\
\hline$U$ & overall heat transfer coefficient $\left(\mathrm{W} / \mathrm{m}^{2} \mathrm{~K}\right)$ \\
\hline$(U A)_{t}$ & $\begin{array}{l}\text { overall heat transfer coefficient from } \\
\text { room to ambient air }(\mathrm{W} / \mathrm{K})\end{array}$ \\
\hline$V$ & volume $\left(\mathrm{m}^{3}\right)$, velocity $(\mathrm{m} / \mathrm{s})$ \\
\hline \multicolumn{2}{|c|}{ Greek symbols } \\
\hline$\alpha$ & absorptivity \\
\hline$\beta$ & packing factor, volume expansion \\
\hline & Coefficient \\
\hline$\theta$ & inclination of roof (rad) \\
\hline$\tau$ & transmissivity \\
\hline$\eta$ & efficiency \\
\hline \multirow[t]{2}{*}{$(\alpha \tau)_{e f f}$} & product of effective absorptivity \\
\hline & and transmittivity \\
\hline$\rho_{a l b}$ & Albedo \\
\hline
\end{tabular}

\section{References}

Hestnes, AG. (1999) Building Integration of Solar Energy Systems. Solar Energy, 67: 181-187.

Ciampi, M., Leccese, F. \& Tuoni, G. (2003) Ventilated facades energy performance in summer cooling of buildings. Solar Energy, 75: 491-502.

Tonui, J.K. \& Tripanagnostopoulos, Y. (2008) Performance improvement of $\mathrm{PV} / \mathrm{T}$ solar collectors with natural air flow operation. Solar Energy, 82: 1-12.

Bazilian, M.D. \& Prasad, D. (2002) Modelling of a photovoltaic heat recovery system and its role in a design decision support tool for building professionals. Renewable Energy, 27: 57-68.

Véronique, D. \& Michaël, K. (2014) A novel approach to compare building integrated photovoltaics/thermal air collectors to side-by-side PV modules and solar thermal collectors. Solar Energy, 100: 50-65.

Kimura, K. (1994) Photovoltaic systems and architecture. Solar Energy Materials and Solar Cells, 35: 409-419.

Taleb, H.M. \& Pitts, A.C. (2009) The potential to exploit use of building-integrated photovoltaics in countries of the Gulf Cooperation Council. Renewable Energy, 34: 1092-1099.

Zhai, X., Wang, R., Dai, Y., Wu, J. \& Ma Q. (2008) Experience on integration of solar thermal technologies with green buildings. Renewable Energy, 33: 1904-1910.

Dapeng, L., Gang, L. \& Shengming, L. (2015) Solar potential in urban residential buildings. Solar Energy, 111: 225-235.

Infield, D., Mei, L. \& Eicker, U. (2004) Thermal performance estimation for ventilated PV facades. Solar Energy, 76: 93-98.

Tripanagnostopoulos, Y., Nousia, T., Souliotis, M. \& Yianoulis, P. (2002) Hybrid photovoltaic/thermal solar systems. Solar Energy, 72: 217-234

Zondag, H., DeVries, D., Van Helden, W., Van Zolingen, R., \& Van Steenhoven, A. (2002) The thermal and electrical yield of a PV-thermal collector. Solar Energy, 72: 113-128.

Prakash, J. (1994) Transient analysis of a photovoltaic-thermal solar collector for co-generation of electricity and hot air/water. Energy Conversion and Management, 35: 967-972.

Chow, T.T., Hand, J. \& Strachan, P. (2003) Building-integrated photovoltaic and thermal applications in a subtropical hotel building. Applied Thermal Engineering, 23: 2035-2049.

Avezov, R., Akhatov, J., \& Avezova, N. (2011) A Review on Photovoltaic Thermal (PV-T) Air and Water Collectors. Applied Solar Energy, 47(3), 169-183.

Tiwari, A., Sodha, MS., Chandra, A. \& Joshi, JC. (2006) Performance evaluation of photovoltaic thermal solar air collector for 
composite climate of India. Solar Energy Materials and Solar Cells, 90: 175-189.

Khaled, T., Mourad, H. \& Ali, M. (2013) Design and modeling of a photovoltaic thermal collector for domestic air heating and electricity production. Energy and Buildings, 59: 21-28.

Parham, A., Mirzaei, Enrico, P. \& Jan, C. (2014) Investigation of the role of cavity airflow on the performance of building-integrated photovoltaic panels. Solar Energy, 107: 510-522.

Maturi, L., Lollini, R., Moser, D. \& Sparber, W. (2015) Experimental investigation of a low cost passive strategy to improve the performance of Building Integrated Photovoltaic systems. Solar Energy, 111: 288-296.

Zondag, H., DeVries, D., Van Helden, W., Van Zolingen, R., \& Van Steenhoven, A. (2002) The thermal and electrical yield of a PVthermal collector. Solar Energy, 72: 113-128.

Fung, T. \& Yang, H. (2008) Study on thermal performance of semitransparent building integrated photovoltaic glazings. Energy and Buildings, 40: 341-350.

Sarhaddi, F., Farahat, S., Ajam, H., Behzadmehr, A. \& Mahdavi, A. (2010) An improved thermal and electrical model for a solar photovoltaic thermal (PV/T) air collector. Applied Energy, 87: 2328-2339.

F. Sarhaddi, S. Farahat, H. Ajam, A. Behzadmehr, "Exergetic optimization of a solar photovoltaic thermal (PV/T) air collector", International Journal of Energy Research, vol. 35, pp. 813-827, 2011.

João, A., Odorico, K., Gustavo, V. \& Cezar, M. (2014) Evaluation of the Photovoltaic Generation Potential and Real-Time Analysis of the Photovoltaic Panel Operation on a Building Facade in Southern Brazil", Energy and building, DOI: http://dx.doi.org/doi:10.1016/i.enbuild.2013.11.007, ENB 4608 PII: S0378-7788(13)00689-0.
Peyvand, S., Rahimi1, M., Parsamoghadam, A. \& Masahi, M. (2014) Using a wind-driven ventilator to enhance a photovoltaic cell power generation. Energy and building, DOI: http://dx.doi.org/doi:10.1016/j.enbuild.2013.12.052, ENB 4744, PII: S0378-7788(13)00869-4.

Agrawal, B. \& Tiwari, G.N. (2010) Optimizing the energy and exergy of building integrated photovoltaic thermal (BIPVT) systems under cold climatic conditions. Applied Energy, 87: 417-426.

Agrawal, B. \& Tiwari, G.N. (2011) Energy and exergy analysis of hybrid micro-channel photovoltaic thermal module. Solar Energy, 85: 356-370.

Vats, K. \& G.N. Tiwari, (2012) Energy and exergy analysis of a building integrated semitransparent photovoltaic thermal (BISPVT) system. Applied Energy, 96: 409-416.

Vats, K. \& Tiwari, G.N. (2012) Performance evaluation of a building integrated semitransparent photovoltaic thermal system for roof and façade. Energy and Buildings, 45: 211-218.

Dubey, S., Sandhu, G.S. \& Tiwari, G.N. (2009) Analytical expression for electrical efficiency of PV/T hybrid air collector. Applied Energy, 86: 697-705.

Özışık, N. (1985) Heat transfer: a basic approach. $1^{\text {st }}$ ed, McGraw-Hill,. Çengel, Y.A. (2003) Heat Transfer: A Practical Approach. $2^{\text {nd }}$ ed, McGraw-Hill,.

Duffie, J.A. \&. Beckman W.A (2013) Solar Engineering of Thermal Processes. 4th ed, Wiley. 